\title{
ОСОБЛИВОСТІ УКЛАДАННЯ ГАЛУЗЕВИХ ГЛОСАРІЇВ
}

Амеліна С. М. Особливості укладання галузевих глосаріїв.

У статті розглядаються питання укладання галузевих глосаріїв. Доведено переваги їх використання в перекладацькій діяльності. Представлено зміст курсу з основ укладання галузевих глосаріїв. Запропоновано урахування алгоритму створення глосаріїв.

Ключові слова: словник, лексикографія, глосарій, термін, перекладач.

Амелина С. Н. Особенности составления отраслевых глоссариев.

В статье рассматриваются вопросы составления отраслевых глоссариев. Доказано преимущества их использования в переводческой деятельности. Представлено содержание курса по основам составления отраслевых глоссариев. Предложено учитывание алгоритма создания глоссариев.

Ключевые слова: словарь, лексикография, глоссарий, термин, переводчик.

Amelina S. M. Features of forming specialized glossaries.

The article deals with the forming specialized glossaries. Benefits of its use in the translation work are proven. The content of the course on the basics of drawing up specialized glossaries is presented. The algorithm of forming glossaries is proposed.

Key words: dictionary, lexicography, glossary, term, translator.

Вирішальне значення для якості перекладу, незалежно від змісту тексту, який перекладається, має правильне використання відповідної термінології. Таким чином забезпечується узгодженість між вихідною та цільовою мовами, ефективність i адекватність перекладу. Адже різночитання під час перекладу термінології можуть негативно вплинути на результат перекладацької діяльності і спричинити труднощі у роботі на основі використання перекладної документації. Тому у професійній діяльності перекладачів часто виникає потреба створення глосаріїв термінів перед початком процесу перекладу.

Мета статті - розглянути особливості укладання галузевих глосаріїв у підготовці майбутніх перекладачів.

Питання створення термінологічних словників та глосаріїв вивчали такі вітчизняні й зарубіжні науковці, як Ф. Важева, Д. Добровольський, Р. Іваницький, В. Карабан, Т. Кияк, В. Лейчик, Д. Мейс, Б. Шуневич та ін. Однак, питання укладання галузевих глосаріїв потребує окремого дослідження. Однією з причин ускладнення процесу перекладу під кутом зору термінології $є$ багатозначність термінів. Термін - мовний знак, що репрезентує поняття спеціальної, професійної галузі науки або техніки. 
Терміни становлять суттєву складову науково-технічних текстів [5].

Тому постає питання укладання галузевих глосаріїв, які можуть значно полегшити діяльність перекладачів. За визначенням Б. Шуневича, глосарій - це продукт лексикографії особливого типу, у якому мовні сутності сприймаються за ідеографічним принципом та концептуальною інтерпретацією [6].

Зазначимо, що при укладанні галузевих глосаріїв доцільно керуватися загальними положеннями щодо створення термінологічних словників, вироблені вітчизняними і зарубіжними лінгвістами. Зокрема, розглядаючи особливості створення термінологічних словників, Б. Шуневич зазначає, що в сучасній лінгвістиці багато зусиль докладено для того, щоб знайти об'єктивні критерії, 3 допомогою яких можна однозначно виділити термінологічні одиниці, що виражають поняття і зв'язки з тією чи тією галуззю знань, і тим самим визначити обсяг і межі термінології. Дослідники по-різному вирішують проблему виявлення термінів у тій чи тій підмові, використовуючи при цьому різні визначення поняття термінів, пропонуючи свої методики добору термінів, критерії їх відбору в разі, коли система понять ще не склалася й немає чіткої межі між терміном і не терміном [6].

Для здійснення підготовки майбутніх перекладачів до створення глосаріїв пропонуємо спецкурс «Основи укладання галузевих глосаріїв», метою якого є: ознайомлення студентів 3 теоретичними основами укладання галузевих глосаріїв; навчання урахування у практиці перекладу наявних галузевих глосаріїв; навчання практичних основ укладання галузевих глосаріїв. При цьому ставляться такі завдання:

- теоретичні: курс спирається на знання студентами лексикології німецької мови. Це дає студентам змогу розширяти коло знань з іноземної та рідної мов з лінгвістичної позиції. При вивченні мови на всіх мовних рівнях, студенти підвищують свою ерудованість, обізнаність та свій інтелектуальний рівень.

- методичні: вивчення курсу дає змогу розв'язати методичну проблему відбору необхідного мовного матеріалу 3 урахуванням особливостей структури іноземної й української мов.

- практичні: курс з основ укладання галузевих глосаріїв має яскраво виражений професійно-перекладацький напрямок i єдину систему теоретичної та практичної підготовки студентів з відповідного курсу.

Вивчення дисципліни допомагає студентам оволодіти теоретичними i практичними засадами предмету, більш глибоко сприймати й аналізувати термінологічний матеріал різних галузей та адекватно його перекладати, сприяє розширенню світогляду, розвитку ерудиції i професіоналізму, заохочує до самостійного мислення, творчості.

У результаті вивчення навчальної дисципліни студент повинен знати:

- особливості лексичної системи іноземної мови; 
- основи лексикографії;

- типи словників;

- особливості глосаріїв;

- теоретичні основи укладання галузевих глосаріїв;

yмimu:

- визначати особливості термінології в певній галузі;

- отримувати $з$ різних джерел інформацію, необхідну для укладання галузевих глосаріїв;

- застосовувати методи лексикографічної обробки лексики;

- відбирати термінологічний матеріал.

Спецкурс «Основи укладання галузевих глосаріїв» передбачає 14 годин лекційних занять, 14 годин практичних занять та 26 годин самостійної роботи з дисципліни, які об’ єднані у два змістові модулі.

Змістовий модуль 1 - «Типологія словників. Глосарії» передбачає такі теми: 1) Лексикографія як наука. Поняття словника; 2) Характеристика словників різних типів; 3) Диференційні ознаки глосаріїв.

Змістовий модуль 2 - «Принципи укладання глосаріїв» передбачає такі теми: 1) Поняття про термін. Особливості галузевої термінології; 2) Моделювання галузевої терміносистеми. Відбір лексики; 3) Внутрішня структура і призначення глосаріїв.

Процес укладання галузевих глосаріїв можна оптимізувати, розробивши його алгоритм. При цьому вважаємо за доцільне звернутися до рекомендованих Б. Шуневичем етапів:

I. Складання плану роботи: 1) скласти список питань, що стосуються впорядкування певної терміносистеми, які потрібно розглянути; 2) визначити розділи майбутнього списку рекомендованих термінів; 3) запланувати впорядкування термінів тих понять, які є основними для певної, а не суміжних спеціальностей.

II. Виявлення і укладання списку термінів, який зручніше укладати за розділами, а не за алфавітом.

III. Систематизація зібраних термінів: 1) у списку повинні бути тільки специфічні поняття терміносистеми, яку потрібно впорядкувати; 2) аналіз значень термінів, тобто виявлення понять, які виражаються цими термінами; 3) виявлення синонімів, багатозначних термінів, які повинні бути вказані до відповідних понять; 4) з'яяясувввання родово-видових зв'язків, що існують між поняттями; 5) розподіл загальних понять для всіх розділів і понять, характерних для окремого розділу; 6) укладання систематизованого словника, що становить сукупність термінів, розташованих відповідно до їх значень, у порядку логічного розташування цих понять.

IV. Формулювання визначень усіх понять, поданих у систематизованому словнику. Варто звертати увагу на такі ключові моменти: 1) фіксувати точний зміст понять; 2) при витлумаченні слід вибирати ті ознаки, які $\epsilon$ 
необхідними і достатніми; 3) не можна подавати окремо взяте визначення, необхідно будувати систему характерних ознак, покладених в основу визначення, що відповідають системі понять; 4) при витлумаченні потрібно брати до уваги не одну ознаку, а однотипно формулювати визначення для цілої групи понять; 5) у визначеннях слід використовувати відомі поняття (терміни) або ті, які пояснювалися раніше; 6) багатозначні терміни мають містити покликання (примітку) на те, в укому значенні їх використано; 7) визначення мають були короткими, складалися 3 одного речення; 8) додаткову інформацію слід подавати у примітках.

V. Відбір термінів і побудова списку рекомендованих термінів: 1) на основі порівняння визначень, зафіксованих у них суттєвих ознак, вибрати рекомендований для певного поняття термін; 2) термін повинен бути коротким і не повинен використовуватися для інших понять відповідної або суміжної спеціальності.

VI. Друкування термінологічного проекту, розсилання його в різні організації, які мають стосунок до окресленої тематики, для широкого обговорення, збору зауважень та їх систематизації.

VII. Уточнення термінів і їх визначень на основі одержаних зауважень, підбір еквівалентів іноземними мовами, підготовка списку рекомендованих термінів для друкування [6].

На нашу думку, створення галузевих глосаріїв має передбачати врахування ще й таких аспектів: а) опора на виконані раніше переклади i глосарії, якщо такі $\epsilon$; б) узгодження нових термінів, які потребують роз'яснення, з відповідними відповідальними особами установи-замовника; в) відповідність глосарію стандартам мов оригіналу й перекладу; г) збереження термінології глосарію для забезпечення послідовності в наступних перекладах аналогічного змісту.

Глосарії можуть містити будь-які мовні елементи: абревіатури, слова, словосполучення, навіть речення. Терміни, представлені у глосаріях, можуть подаватися у звичайному перекладі або ж супроводжуватися тлумаченням із коментарем мовою перекладу чи мовою оригіналу.

Професійна діяльність перекладачів передбачає вміння створення глосаріїв термінів відповідної галузі, на перекладах із якої спеціалізується перекладач. Процес укладання галузевих глосаріїв відбувається за певним алгоритмом. Переваги галузевих глосаріїв полягають у поліпшенні якості перекладу завдяки забезпеченню єдності термінології; у скороченні терміну виконання перекладу; в адаптації до стандартів; у зменшенні неточностей і уникненні помилок.

Перспективи подальшого дослідження пов'язані із розробкою основ укладання галузевих глосаріїв. 


\section{Література}

1. Білозерська Л. П. Термінологія та переклад : [навч. посібник для студентів філологічного напряму підготовки] / Л. П. Білозерська, Н. В. Возненко, С. В. Радецька. - Вінниця : Нова книга, 2010. - 232 с.

2. Важева Ф. А. Некоторые принципы систематизации терминов и понятий (на материале социологии) / Ф. А. Важева // Место терминологии в системе современных наук. - М. : Изд-во МГУ, 1970. - С.71-75.

3. ДСТУ 3966-2000 Термінологія. Засади і правила розроблення стандартів на терміни та визначення понять. - К. : Держстандарт України, 2000. - 32 с.

4. Іваницький Р. В. Лексикографічні аспекти нормалізації термінів : автореф. дис. ... канд. філол. наук : 10.02.04 / Р. В. Іваницька. - Львів, 1995. - 20 с.

5. Карабан В. І. Теорія і практика перекладу з української мови на англійську мову : [посіб.-довід.] / В. І. Карабан, Дж. Мейс. - Вінниця : Нова книга, 2003. - 606 с.

6. Шуневич Б. Про упорядкування нових терміносистем / Б. Шуневич // Вісник ДУ «Львівська політехніка» «Проблеми української термінології» : матеріали 6-ї Міжнародної наукової конференції [«СловоСвіт 2000»]. - 2000. - № 402 - С. 85-87.

7. Dobrovolskiy D. Phraseologie und Sprachliche Weltbuld (Vorarbeiten zum Thesaurus der Deutschen Idiomatik) / D. Dobrovolskiy // Deutsche Phraseologie in Sprachsystem und Sprachwendung. - 1992. - S. 171-196. 